\title{
"Genjer" Yellow Velvetleaf used as indigenous vegetable in Indonesia
}

\section{Ant J Bot Ale}

Received : 29.03.2020 Accepted : 01.05 .2020 Online $\quad: 05.05 .2020$

\author{
Achmad Yozar PERKASA ${ }^{1,2 *}$, , Spiros PETROPOULOS ${ }^{3} \odot$ \\ ${ }^{1}$ Gunadarma University, Faculty of Technology Industry, Department Agrotechnology, Depok, Indonesia \\ ${ }^{2}$ Ankara University, Faculty of Agriculture, Department of Field Crops, Ankara, Turkey \\ ${ }^{3}$ Thessaly University, Faculty of Agriculture, Dept. Agriculture, Crop Prod. and Rural Env., Volos, Greece \\ *perkasa@ankara.edu.tr, ${ }^{3}$ spetropoulos@uth.gr
}

\section{Endonezya'da yerli sebze olarak kullanılan “Genjer” Sarı Kadife Yaprak}

\begin{abstract}
Indigenous vegetables are native to or originating from a particular region or ecosystem. Indigenous vegetables may have evolved from foreign plants introduced to the region from another geographical area over a long period of time. Limnocharis flava (L.) Buch. (sawah lettuce, velvet leaf) had an enormous impact on agriculture and food systems all over the world especially has been identified as exotic weed invasion. This plant appears in the aquatic environment and included in the Limnocharitaceae family. Yellow Velvetleaf ( L. flava) has been utilised in Indonesia as vegetable and animal feed. Processing of this plants is done by steaming, boiling, and stirfrying. Young leaves with petioles and young, unopened inflorescences are eaten as a vegetable in Indonesia, especially in West Java region.
\end{abstract}

Key words: Genjer, indigenous vegetable, Indonesia, Limnocharis flava

Özet: Yerli sebzeler, belirli bir bölge veya ekosisteme özgüdürler veya bu bölgeden kaynaklanırlar. Yerli sebzeler uzun bir süre boyunca bölgeye başka bir coğrafi bölgeden tanıtılan yabancı bitkilerden evrilmiş olabilirler. Limnocharis flava (L.) Buch. (bataklık marulu, kadife yaprağı) tüm dünyada tarım ve gıda sistemleri üzerinde büyük bir etkiye sahiptir, özelikle ekzotik ve istilacı bir yabani ot olarak tanımlanmaktadır. Bu bitki su ortamında görülür ve Limnocharitaceae ailesine dahildir. Sarı Kadife Yaprak (L. flava) Endonezya'da sebze ve hayvan yemi olarak kullanılmaktadır. Bu bitkinin işlenmesi buharda pişirilerek, kaynatılarak ve karıştırılarak yapılır. Saplı genç yapraklar ve açılmamış genç çiçek durumları Endonezya'da, özellikle Batı Java bölgesinde sebze olarak yenir.

Anahtar Kelimeler: Genjer, yerli sebze, Endonezya, Limnocharis flava

Citation: Perkasa AY, Petropoulos S (2020). “Genjer” Yellow Velvetleaf used as indigenous vegetable in Indonesia. Anatolian Journal of Botany 4(1): 76-79.

\section{Introduction}

Worldwide, 1500 to 2000 plant species have been used as vegetables; for Southeast Asia, the number is close to 1000 species (Siemonsma and Piluek, 1994). About 120 species are cultivated for sale or home consumption. Indigenous vegetables have become popular in recent Indonesian diet, but agronomic studies on these crops are limited (Santosa et al., 2015). Indigenous vegetables are native to or originating from a particular region or ecosystem. They may have evolved from foreign plants introduced to the region from another geographical area over a long period of time. Indigenous vegetables are mainly planted in home gardens, or used by a small group of people in a limited geographical area (Engle and Faustino, 2007). In some cases, these plants naturalized and evolved in the new environment; such as Limnocharis flava (L.) Buch. (sawah lettuce, velvet leaf) brought from Central America to Southeast Asia (Siemonsma and Piluek, 1994) as part of the great transmigration of plants that followed the voyages of Christopher Columbus to the Americas, which had an enormous impact on agriculture and food systems all over the world.

This plant appears in the aquatic environment and included in the family Limnocharitaceae. Factors which influences the existence of L. flava are land use or land cover pattern, depth water, nutrients, and associations with other species (Abhilash et al., 2008). The utilization of yellow velvetleaf can be implemented for human, environment, and livestock. Commonly, this plant is consumed by human as vegetable due to its fibre. Furthermore, yellow velvetleaf is also used as livestock feed and fish feed, phytofiltration plant for eliminating pollution in the water, an ornamental plant in pond, and fertilizer (Abhilash et al., 2009). Research of Maisuthisakul et al. (2008) shows that L. flava in the Thailand region contains a total phenolic of $5.4 \mathrm{mg}$ $\mathrm{GAE} / \mathrm{g} \mathrm{db}$ and total flavonoids of $3.7 \mathrm{mg} \mathrm{RE} / \mathrm{g} \mathrm{db}$. Research of Ogle et al. (2001) show that L. flava contains carotene as much as $50 \mu \mathrm{g} / \mathrm{g}$.

Yellow Velvetleaf processing in Indonesia is done by steaming, boiling, and stirfrying. Steaming is the process of heating at more water temperature from 66 to $82^{\circ} \mathrm{C}$, aiming to deactivate the enzyme and change the color, taste, and nutritional value (Jacoeb et al., 2010). The aim of this paper is to give information about the ethnobotany and the importance of Genjer in Indonesia as an indigenous vegetable.

\section{Yellow Velvetleaf (Limnocharis flava (L.) Buch)}

\subsection{Description and classification}

Limnocharis flava (Fig. 1) is a perennial, robust, erect, lactiferous, marsh herb, $20-100 \mathrm{~cm}$ tall, rooting in mud and strongly tillering. Leaves basal, rosulate, glabrous, longpetioled, orbicular or ovate, $5-30 \times 4-25 \mathrm{~cm}$, entire, yellowish-green, curvinerved, transversely latticed-veined, underneath at apex with a purple-rimmed water pore, folded lengthwise in bud; with numerous air chambers, 5$75 \mathrm{~cm}$ long. Inflorescence axillary, long-peduncled, umbelliform, glabrous, 5-15-flowered, erect, recurved after 
fruiting until it reaches the water or mud; peduncles 10-90 $\mathrm{cm}$ long. Flowers rather large, in the axils of membranous bracts; pedicels 3-7 cm long; sepal 3, enlarged and clasping the fruit after anthesis, yellow-green, ovate-elliptic, 7-25 $\times$ 5-15 mm; petals 3, pale yellow, obovate, very thin, $1.5-3 \times$ $0.7 \times 2 \mathrm{~cm}$, becoming a slimy mass after anthesis; apex rounded, base darker coloured. Stamens more than 15, surrounded by a whorl of staminodes. Ovaries numerous in one whorl, superior, laterally much compressed, simulating a single, deeply incised ovary; stigmas narrowly linear, sessile. Compound fruit $1.5-2 \mathrm{~cm}$ in diameter, enclosed by the sepals. Seeds numerous, minute, horseshoe-shaped, dark brown, 1-15 mm long, testa spongy with thin tranverse ridges (CABI, 2019).

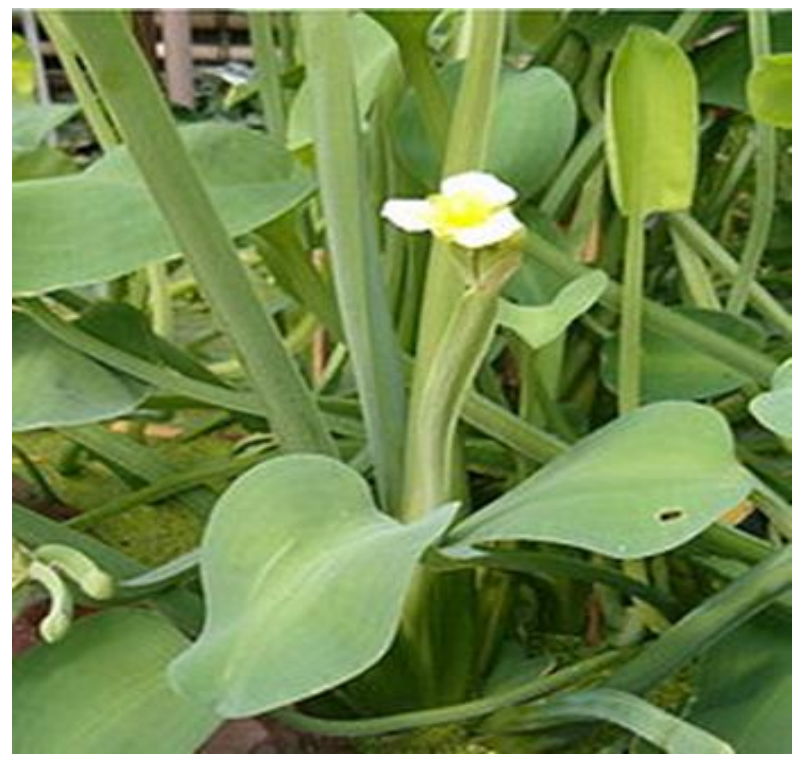

Figure 1. Limnocharis flava habit (Plantmor, 2019).

Edible parts of Genjer are the petioles, leaf blades, peduncles, and the unopened inflorescences.

The very large and somewhat fleshy leaves (Fig. 2) arise from the base of the plant, and are borne in clusters along a short thick upright (i.e. erect) stem (about $3 \mathrm{~cm}$ long and 3 cm wide).

The leaves are hairless (i.e. glabrous) and contain a milky sap (i.e. latex). They are borne on long three-angled stalks (i.e. trigonous petioles) $5-90 \mathrm{~cm}$ long and have rounded (i.e. orbicular) leaf blades. The leaf blades $(5-30 \mathrm{~cm}$ long and 4$25 \mathrm{~cm}$ wide) have blunt tips (i.e. obtuse apices) and entire or wavy (i.e. undulate) margins (Lucidcentral, 2019).

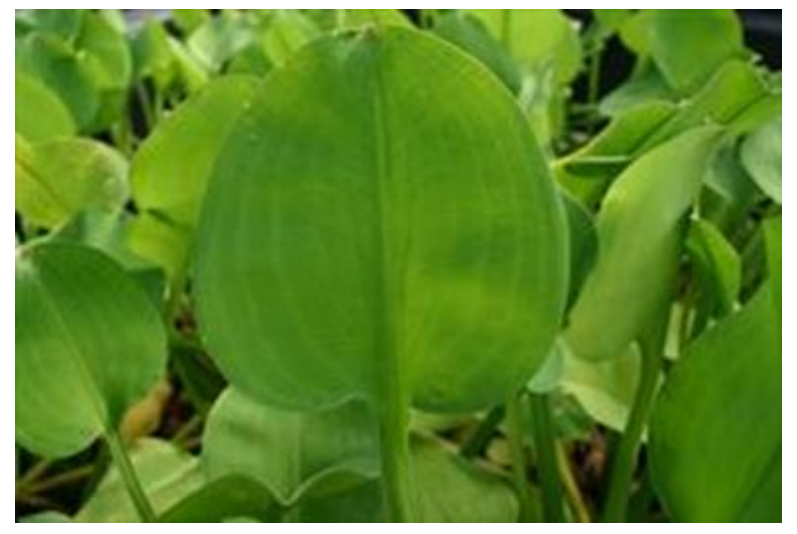

Figure 2. Limnocharis flava leaves (Keyserver, 2019).
The flowers (Fig. 3) are borne in loose clusters (containing 2-15 flowers) at the top of long stalks (20-120 cm long). These upright flower stalks (i.e. erect peduncles) emerge from the base of the plant and are three-angled (i.e. trigonous), like the leaf stalks (i.e. petioles). About one to four of these flowering stalks are produced amongst each cluster of leaves.

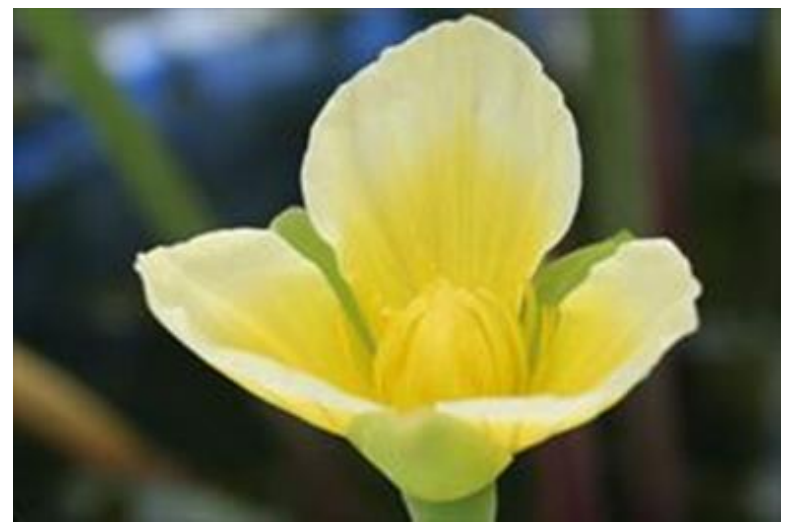

Figure 3. Limnocharis flava flower (Keyserver, 2019).

The individual flowers $(2-4 \mathrm{~cm}$ across $)$ are borne on short thick stalks (i.e. pedicels), $2-7 \mathrm{~cm}$ long, that emerge from the same point at the top of the flowering stems (i.e. they are arranged in an umbel). There are usually some small papery bracts present amongst the flower stalks (i.e. pedicels). Each flower has three large pale yellow petals (20-30 $\mathrm{mm}$ long and 10-20 mm wide), three overlapping green sepals (15-20 mm long and 10-15 mm wide), and a cluster of numerous bright yellow stamens at its centre. Flowering occurs throughout the year, depending on conditions (i.e. it usually flowers during wetter periods) (Lucidcentral, 2019).

The upright flower stalks (i.e. peduncles) begin to droop as the fruit mature, and the persistent sepals become enlarged and enclose the developing fruit. The fruit are rounded 'capsules' (i.e. spherical follicles), 15-20 mm across, that split up into several (10-20) floating segments when mature. Each segment is semi-circular in shape and contains numerous ridged seeds (1-1.5 mm long) that are dark brown in colour and horseshoe-shaped (Lucidcentral, 2019).

Limnocharis flava flowers the whole year round. The flowers open in the morning and close after a few hours. There is no record of any pollinating agent. After anthesis, the sepals enlarge and surround the fruit whereas the petals become a slimy mass. When ripe, the fruit carpels fall into the water where they release the seeds, which sink to the bottom. The downturned inflorescence which rests on the water surface often produces a new plant (Van den Bergh, 1993).

This species reproduces by seed (Fig. 4) and vegetatively via creeping underground stems (i.e. rhizomes). Small plants (i.e. ramets) are sometimes also produced at the tops of the flowering stems.

Although it is not a floating plant, its seeds are carried away by water streams. Yellow velvetleaf grows generally wherever there is not very deep stagnant fresh water, in swampy areas. It sometimes invades rice fields where it can become a weed. As an invasive species it has become a pest in some wetlands in other parts of the World (Santosa et al., 
2015). The seeds and vegetative shoots are usually spread by water, but may also be dispersed in dumped garden and aquarium waste.

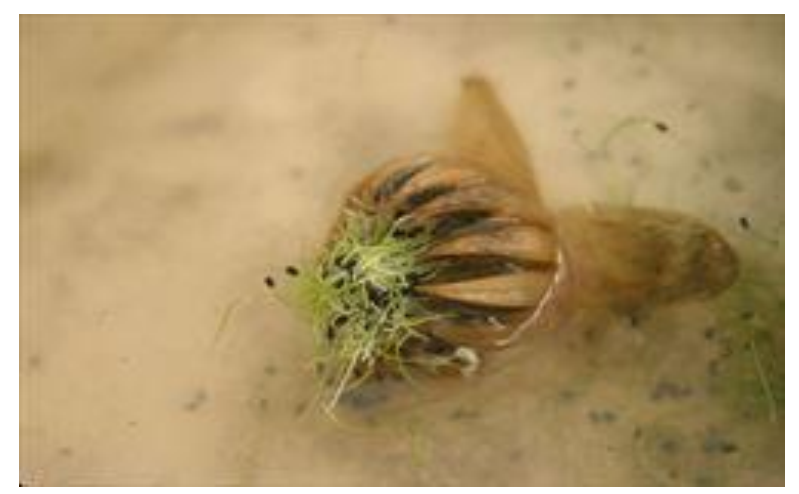

Figure 4. Limnocharis flava seeds (Keyserver, 2019).

The position in classification and the taxonomic hierarchy for L. flava as follows (CABI, 2019).

\section{Domain: Eukaryota}

Kingdom: Plantae

Phylum: Spermatophyta

Subphylum: Angiospermae

Class: Monocotyledonae

Order: Hydrocharitales

Family: Limnocharitaceae

Genus: Limnocharis

Species: Limnocharis flava

\section{Limnocharis flava (L.) Buchenau}

Syn : Alisma flava L., Damasonium flavum (L.) Mill. Gard., Limnocharis emarginata Humb. et Bonpl., Limnocharis laforesti Duchas. Ex Griseb, Limnocharis mattogrossensis O. Ktze., Limnocharis plumieri Rich., Mem.

International common names of $L$. flava are Hermit's waterlily, sawah lettuce, velvet leaf, yellow sawah lettuce, yellow velvetleaf, yellow bur-head (English); Cebolla de chucho (Spanish); Buchon (French). But the preferred common name is Yellow bur-head.

Local common names used for L. flava are Kalmi or kengkong (Bangladesh); Barata (Brazil); Trakiet (Cambodia); Manja payal (India); Bangeng, eceng, enceng, berek, gunda, genjer (Indonesia); Kibana omodaka (Japan); Kaanz choong (Laos); Jinjir, paka rawan, paku rawan (Malaysia); Bon cheen, taalapat ruesee, bonchin, nangkwak, talapatrusi (Thailand); k[ef]o $\mathrm{n}[\mathrm{ef}] \mathrm{o}$; $\mathrm{n}[\mathrm{ee}]$ th[ar]o (Vietnam).

\subsection{Habitat and distribution}

Limnocharis flava is a perennial herb that prefers wet conditions such as lowland ricefields, and shallow waters in canals, swamps, pools and ditches. In Kerala, India, the weed density decreases as water depth increases, as L. flava is a rooted emergent preferring shallow water bodies and marshy areas (Abhilash et al., 2008). Abandoned paddy fields and reclaimed coconut fields with marshy areas are the main habitat in Kerala. The soil is generally fertile in areas where the weed occurs.
Though it is a perennial, L. flava behaves as an annual in certain habitats. It reproduces by seed and vegetatively (by stolons). It is hydrochorous, and is a prolific seedproducing plant, with individual plants capable of yielding up to $1,000,000$ seeds per year. The mechanism of seed dispersal is discussed in Nayar and Sworupanandan (1978).

Limnocharis flava is spread throughout South-East Asia (Malaysia, Indonesia, Thailand, South Myanmar, Sri Lanka, India and Vietnam), especially in rice-growing areas, and in South America and the USA. It has recently been reported in northern Queensland, Australia, where it is the target of an eradication campaign (Waterhouse et al., 2003).

\subsection{History of introduction and spread}

Limnocharis flava is native to tropical and subtropical America (i.e. northwestern Mexico, Nicaragua, Costa Rica, Panama, Cuba, Haiti, Dominican Republic, Windward Islands, Colombia, Venezuela, Ecuador, West Indies, Peru and Brazil) and has been introduced to southern USA and parts of Asia. It was introduced into Southeast Asia from tropical and subtropical America, and naturalized in Indonesia, Malaysia and Thailand (Van den Bergh, 1994). Abhilash et al., (2008) report that the earliest record of its introduction to Asia is as an ornamental in the Botanic Garders, Bogor, Indonesia in 1866, and that by 1870 it was mentioned as 'a newly introduced alien' on the banks of the river flowing through the Botanic Gardens. It now occurs throughout Indonesia and the rest of South-East Asia. Abhilash et al., (2008) describe its spread in Asia. In Sri Lanka it was introduced as an ornamental in 1998 and subsequently became naturalized and a serious weed in rice fields.

It propagates mainly by seeds. Sometimes they are also carried with the mud sticking to the feet of birds, by man and agricultural implements (Kotalawala, 1976). L. flava seeds throughout the year. A single fruit produces about 1,000 seeds and a single plant may produce as $1,000,000$ seeds per year. Human agency is also responsible for the spread of this plant due to the popular belief that the leaves of this plant, when eaten as a partly cooked salad, cures rheumatism. Some have deliberately planted this weed without realizing the danger to rice fields when it gets out of control.

\subsection{Uses and Agronomy}

Young leaves with petioles and young, unopened inflorescences are eaten as a vegetable in Indonesia, especially West Java, in Malaysia and in Thailand. Usually they are not eaten raw but heated above a fire or cooked for a short time. The older leaves have a bitter taste. Whole plants are given as fodder to pigs or fish. L. flava also serves as an ornamental plant in ponds. Plants are often ploughed in as green manure in rice fields (PROSEA, 2019).

Limnocharis flava can be cultivated the whole year round. It is propagated by layers, but propagation by seed is also possible. It needs a fertile soil; 1-2 weeks before planting, the soil should be enriched with organic fertilizer (10 t/ha). Planting distance is about $30 \mathrm{~cm}$ square. In a fertile sawah it will grow very fast and the leaves and inflorescences can 
be harvested after 2-3 months. If not harvested regularly the plant population will soon become too dense and should be renewed to maintain quality. After harvesting, the leaves and inflorescences are bundled together or separately and sold in small bunches (PROSEA, 2019).
In West Java L. flava is a common vegetable in markets and supermarkets but data on production are rare. In an integrated system of pisciculture and genjer cultivation, an Indonesian farmer harvested about 1000 bunches/ha in 3 months ( 1 bunch $=20$ sprouts) (PROSEA, 2019).

\section{References}

Abhilash PC, Pandey VC, Srivastava P, Rakesh PS, Chandran S, Singh N, Thomas AP (2009). Phytofiltration of cadmium from water by Limnocharis flava (L.) Buchenau grown in free floating culture system. Journal of Hazardous Materials 170(2-3): 791-797.

Abhilash PC, Singh N, Sylas VP, Kumar BA, Mathew JC, Satheesh R, Thomas AP (2008). Eco-distribution mapping of invasive weed Limnocharis flava (L.) Buchenau using geographical information system: implications for containment and integrated weed management for ecosystem conservation. Taiwania 53(1): 30-41.

CABI. https://www.cabi.org/isc/datasheet/30804\#tosummaryofInvasiveness / [accessed 13 November 2019].

Engle LM, Faustino FC (2007). Conserving the indigenous vegetable germplasm of Southeast Asia. Acta Horticulturae 752: 55-60.

Jacoeb AM, Abdullah A, Rusydi R (2010). Characteristic of microscopic and bioactive compound of Yellow Velvetleaf (Limnocharis flava) from Situ Gede Bogor. Journal of Aquatic Resources 4(2): 1-6.

Keyserver. https://keyserver.lucidcentral.org/weeds/data/media/html/limnocharis_flava.htm / [accessed 13 November 2019].

Kotalawala J (1976). Noxious water vegetation in Sri Lanka: the extent and impact of existing infestations. In Varshney CK, Rzoska J (ed.). Aquatic weeds in S.E. Asia. Proceedings of a regional seminar on noxious aquatic vegetation, New Delhi, 1973. Pp. 51-58.

Lucidcentral. https://www.lucidcentral.org / [accessed 13 November 2019].

Maisuthisakul P, Pasuk S, Ritthiruangdej P (2008). Relationship between antioxidant properties and chemical composition of some Thai plants. Journal of Food Composition and Analysis 21(3): 229-240.

Nayar BK, Sworupanandan K (1978). Morphology of the fruit and mechanism of seed dispersal of the freshwater weed Limnocharis flava. Proceedings of the Indian Academy of Sciences, Section B, 87(2):49-53.

Ogle BM, Johansson M, Tuyet HT, Johannesson L (2001). Evaluation of the significance of dietary folate from wild vegetables in Vietnam. Asia Pacific Journal of Clinical Nutrition 27(10): 216-221.

Plantamor (Informasi Spesies). http://www.plantamor.com / [accessed 13 November 2019].

PROSEA. https://uses.plantnet-project.org/en/Limnocharis_flava_(PROSEA) / [accessed 13 November 2019].

Santosa E, Prawati U, Sobir, Mine Y, Sugiyama N (2015). Agronomy, utilization and economics of indigenous vegetables in West Java, Indonesia. Jurnal Hortikultura Indonesia 6(3): 125-134.

Siemonsma JS, Piluek K (1994). Plant resources of South-East Asia. No. 8, Vegetables. Bogor: Prosea Foundation.

Van den Bergh MH (1993). Limnocharis flava (L.) Buchenau. In: Siemonsma JS, Piluek K, (eds.). Plant resources of South-East Asia 8. Vegetables. Wageningen: Pudoc Scientific Publishers.

Van den Bergh MH (1994). Limnocharis flava (L.) Buchenau. In Siemonsma JS, Piluek K, (eds.). PROSEA 8. Vegetables. Bogor: Prosea Foundation Indonesia.

Waterhouse BM, Everett J, Wilson PG (2003). Know your enemy: recent records of potentially serious weeds in northern Australia, Papua New Guinea and Papua (Indonesia). Proceedings of the 5th International Flora Malesiana Symposium, Sydney, Australia, September 2001. Telopea, 10(1): 477. 